\title{
Silicon leaf application and physiological quality of white oat and wheat seeds
}

\section{Aplicação foliar de silício e qualidade fisiológica de sementes de aveia-branca e trigo}

\author{
Mariana Zampar Toledo ${ }^{1 *}$; Gustavo Spadotti Amaral Castro²; \\ Carlos Alexandre Costa Crusciol ${ }^{3}$; Rogério Peres Soratto³; Cláudio Cavariani³; \\ Mariane Sayuri Ishizuka ${ }^{4}$, Laís Bilia Picoli ${ }^{4}$
}

\begin{abstract}
Plant nutrition can positively influence quality of seeds by improving plant tolerance to adverse climate. In this context, silicon is currently considered a micronutrient and it is beneficial to plant growth, especially Poaceaes such as white oat and wheat, thereby improving physiological quality of seeds. This study had the objective of evaluating the effects of silicon leaf application on plant tillering, silicon levels and physiological quality of white oat and wheat seeds besides establishing correlations between them. Two experiments were carried out in winter with white oat and wheat. The experimental design was the completely randomized block with eight replications. Treatments consisted of foliar application of silicon ( $0.8 \%$ of soluble silicon, as stabilized orthosilicic acid) and a control (with no application). Silicon levels in leaves were determined at flowering whereas the number of plants and panicles/spikes per area was counted right before harvest. Seed quality was evaluated right after harvest through mass, germination and vigor tests. Data was submitted to variance analysis and means were compared by the Tukey test at a probability level of 5\%. Person's linear correlation test was performed among silicon level in plants, tillering and seed quality data. Silicon leaf application increases root and total length of white oat seedlings as an effect of higher Si level in leaves. Silicon leaf application increases mass of wheat seeds without affecting germination or vigor.
\end{abstract}

Key words: Avena sativa L., Triticum aestivum L., germination, vigor, plant nutrition, orthosilicic acid

\section{Resumo}

A nutrição das plantas pode influenciar positivamente a qualidade das sementes por proporcionar maior tolerância às adversidades climáticas. Neste contexto, o silício é atualmente considerado um micronutriente e tem efeito benéfico no crescimento das plantas, especialmente Poaceaes como aveia-branca e trigo, consequentemente melhorando a qualidade fisiológica das sementes. Este estudo objetivou avaliar os efeitos da aplicação foliar de silício no perfilhamento e teor do nutriente nas plantas e na qualidade fisiológica das sementes de aveia-branca e trigo além de estabelecer correlações entre os fatores. Foram realizados dois experimentos conduzidos no inverno com as culturas da aveia-branca e do trigo. O delineamento experimental foi o de blocos ao acaso, com oito repetições. Os tratamentos

${ }^{1}$ Prof ${ }^{a}$ Colaboradora Adjunta, Universidade Estadual de Maringá, UEM, Campus Regional de Umuarama, Umuarama, PR. E-mail: zampar_@hotmail.com

${ }^{2}$ Analista A. Embrapa Amapá, Macapá, AP. Email: gsacastro@hotmail.com

${ }^{3}$ Profs. Drs., Faculdade de Ciências Agronômicas, FCA/UNESP, Botucatu, SP. E-mail: crusciol@fca.unesp.br; soratto@fca.unesp. br; ccavariani@fca.unesp.br

${ }^{4}$ Discente(s) de Graduação, Faculdade de Ciências Agronômicas, FCA/UNESP, Botucatu, SP. E-mail: msishizuka@fca.unesp.br; lbpicoli@fca.unesp.br

* Author for corespondence 
constaram da aplicação foliar de silício $(0,8 \%$ de silício solúvel, aplicado na forma de ácido ortosilícico estabilizado) e uma testemunha (sem aplicação). O teor de silício nas folhas foi determinado no florescimento; já a avaliação do perfilhamento, o número de plantas e de panículas/espigas por área foi determinado anteriormente à colheita. A qualidade das sementes foi avaliada logo após a colheita por meio de testes de massa, germinação e vigor. Os dados foram submetidos à análise de variância e as médias comparadas pelo teste de Tukey a $5 \%$ de probabilidade. O teste de correlação linear de Person foi aplicado a fim de relacionar o teor de silício nas plantas, o perfilhamento e a qualidade das sementes. A aplicação foliar de silício aumenta o comprimento da raiz primária e total das plântulas de aveiabranca decorrente do maior teor de silício nas folhas. A aplicação foliar de silício aumenta a massa das sementes de trigo sem, contudo, afetar a germinação e o vigor.

Palavras-chave: Avena sativa L., Triticum aestivum L., germinação, vigor, nutrição de plantas, ácido ortosilícico

\section{Introduction}

White oat (Avena sativa L.) and wheat (Triticum aestivum L.) are important winter cereals cultivated mainly in Central-Southern Brazil, although both of them have been widely cropped in no-till rotation systems in many other regions. In 2011/2012, the total area cropped with oat and wheat was 0.15 and 2.17 million hectares, respectively, totaling almost 2.5 million hectares; total production exceeded 6.0 millions of tons (CONAB, 2012).

Among the efforts to improve crop production, there have been studies about seed technology such as the one developed by Toledo et al. (2011). For instance, Copeland and McDonald (2001) stated that plant nutrition is among the factors that may influence seed vigor. According to Sá (1994), well fertilized plants may produce higher number of seeds per area with better physiological quality, once those may become even more tolerant to climate adversities.

Although silicon ( $\mathrm{Si}$ ) is not considered an essential element for plant growth (MARSCHNER, 1995), some silicates have been increasingly used in agriculture, mainly due to several benefits to plant development, especially Poaceaes. Some of them are related to $\mathrm{Si}$ deposition on cell wall of many plant organs (MA; YAMAJI, 2006), especially leaves. Si accumulation decreases transpiration and water uptake, being an important mechanism for plants grown under drought conditions (MELO et al., 2003). Additionally, these may be more erect and a larger leaf area would be exposed to light (EPSTEIN, 1999). Some studies have also shown that $\mathrm{Si}$ is effective in mitigating salinity in different plant species, such as wheat (TUNA et al., 2008). Besides, Si may increase superoxide dismutase, peroxidase, and catalase activities in barley and maize (MOUSSA, 2006). Other benefits from Si include increased dry mass and yield, enhanced pollination (KORNDÖRFER; LEPSCH, 2001) and most commonly increased disease resistance (RODRIGUES et al., 2004).

Benefits from silicon may be observed especially in Si accumulating-grasses such as wheat and oat, for they show Si levels higher than 1\% in leaves (MA; MIYAKE; TAKAHASHI, 2001). According to Lima Filho and Tsai (2007), both species are highly efficient in Si uptake and increasing absorption if this element is supplied in soil in higher contents. Quality of seeds from those crops may be influenced not directly but somehow by better conditions for plant development. Plants which are tolerant to biotic and abiotic stress are more likely to produce well formed and high quality seeds. For instance, Harter and Barros (2011) found that soybean plants treated with calcium and silicon produce seeds with higher physiological quality.

In rice, Mauad et al. (2003) have found Si to significantly affect seed mass. According to Marcos Filho (2005), heavier seeds usually have better developed embryos and higher amount of reserves. Lee et al. (1985) also observed, in rice, that silicate 
application improved seed coat development, affecting physiological quality (KORNDÖRFER et al., 2001). Being a precursor for the synthesis of lignin, Si may improve coat resistance and decrease seed susceptibility to mechanical damage and metabolite leaching. Upon studying the effects of $\mathrm{P}$ and Si applied in soil, Toledo et al. (2011) reported lower electrical conductivity of white oat seeds with increasing Si doses and higher P supply.

Leaf application of lower silicon rates have been reported as efficient and viable for supplying and/ or stimulating Si absorption (SOUSA et al., 2010). Therefore, this study had the objective of evaluating the effects of silicon leaf application on plant

Figure 1. Rainfall ( ) , minimum (……), maximum experiment. tillering, silicon levels and physiological quality of white oat and wheat seeds besides establishing correlations between them.

\section{Material and Methods}

Two experiments were installed and conducted in 2008 winter season in College of Agricultural Sciences, UNESP, Botucatu-SP, Brazil. Geographical coordinates are $48^{\circ} 26^{\prime} \mathrm{W}, 22^{\circ} 51^{\prime} \mathrm{S}$ and $740 \mathrm{~m}$ above sea level. According to Köeppen's classification, climate is Cwa, which corresponds to tropical altitude with dry winter and hot wet summer. Climate data during the experiment is shown in Figure 1.

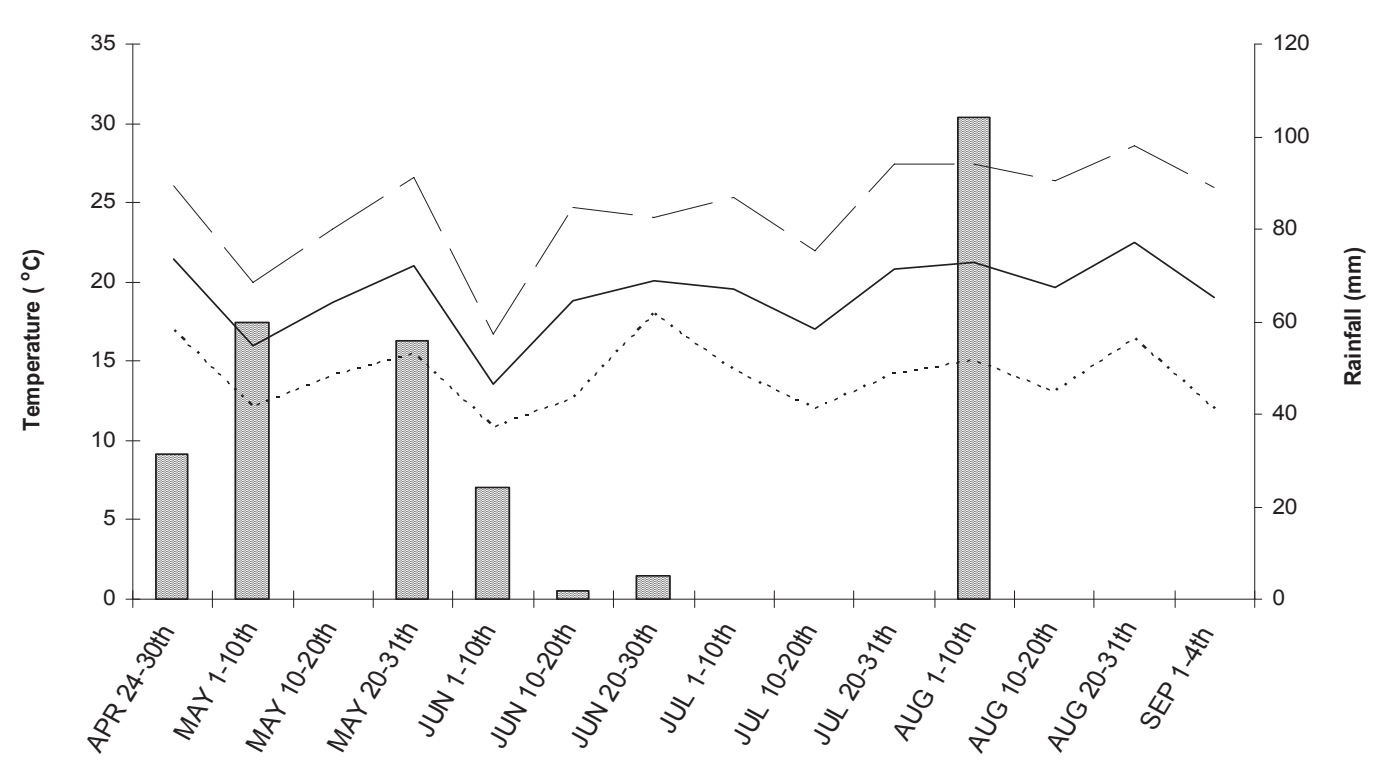

Source: Elaboration of the authors. 
Soil in the area is a Typic Haplustox (FAO, 2006). Chemical attributes in each experimental area were determined through soil sampling $(0-20 \mathrm{~cm})$ and analysis according to Raij et al. (2001). Results were: organic matter: $25.0 \mathrm{~g} \mathrm{dm}^{-3} ; \mathrm{pH}\left(\mathrm{CaCl}_{2}\right)$ : 5.4; $\mathrm{P}$ (resin): $18.0 \mathrm{mg} \mathrm{dm}^{-3} ; \mathrm{K}, \mathrm{Ca}, \mathrm{Mg}$ and $\mathrm{H}+\mathrm{Al}: 4.9$, 47.0, 21.0 and $32.0 \mathrm{mmol}_{\mathrm{c}} \cdot \mathrm{dm}^{-3}$, respectively; base saturation: $70.0 \%$.

The two experiments consisted of white oat and wheat winter cropping under the completely randomized block design with eight replications. Treatments were leaf application of silicon and a control (with no application). Thirteen 5-m plant rows were sown but only 9 central rows were considered as the useful area, except $0.5 \mathrm{~m}$ of each extremity.

White oat cultivar 'IAC 7' and wheat cultivar 'Coodetec 107' were sown on April 24 2008 at $0.17-\mathrm{m}$ row spacing and 50 seeds- $\mathrm{m}^{-1}$ rate. Base fertilization consisted of 17,60 and $34.5 \mathrm{~kg} \mathrm{ha}^{-1}$ of $\mathrm{N}, \mathrm{P}_{2} \mathrm{O}_{5}$ and $\mathrm{K}_{2} \mathrm{O}$, respectively, applied as 04-1408 NPK formula. Side dressing was conducted at tillering and $65 \mathrm{~kg} \mathrm{ha}^{-1}$ of $\mathrm{N}$ as ammonium sulphate was applied (RAIJ et al., 1996). Sowing and base fertilization were mechanically carried out under no tillage system. Seeds were previously treated

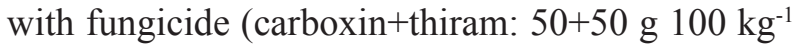
of seeds). Seedling emergence took place 8 days after sowing. Management practices for both crops, normally used in the region, included insecticide application on June $7^{\text {th }}$ (chlorpyriphos $-336 \mathrm{~g}^{-}$ $\left.{ }^{1}\right)$ and insecticide/fungicide applications on July $27^{\text {th }}$ (methamidophos $-120 \mathrm{~g} \mathrm{ha}^{-1}$; epoxyconazol+ pyraclostrobin $-50+133 \mathrm{~g} \mathrm{ha}^{-1}$ ).

Silamol $^{\circledR}(0.8 \%$ of soluble $\mathrm{Si}$, as stabilized orthosilicic acid $\left[\mathrm{Si}(\mathrm{OH})_{4}\right], 48 \%$ polyethilene glicol 400) was applied for Si supply according to recommendations of the manufacturer. Application was conducted with a knapsack sprayer for a calculated volume of $200 \mathrm{~L} \mathrm{ha}^{-1}$. The total dose of $2.0 \mathrm{~L} \mathrm{ha}^{-1}$ was split in three different stages of both crops, i.e., applications of $666.7 \mathrm{~mL} \mathrm{ha}^{-1}$ at tillering, bud differentiation and booting stages.

At full flowering, the flag leaf of 50 white oat plants per plot was sampled; sampling of wheat leaves took place at the beginning of flowering, when the first to fourth leaf from the apices of 30 plants were collected (MALAVOLTA; VITTI; OLIVEIRA, 1997). Silicon levels in plants were evaluated according to Korndörfer, Pereira and Nolla (2004).

Right before mechanical harvest, on September $4^{\text {th }} 2008$, the number of plants and panicles/spikes per area was counted for tillering evaluations.

Seeds were then stored in paper bags under environmental conditions during the analyses. Seeds were evaluated right after harvest by the following tests:

Moisture content: two subsamples of 20 seeds per treatment were evaluated using an oven at $105 \pm$ $3^{\circ} \mathrm{C}$ for $24 \mathrm{~h}$ (wet basis); results were expressed as a percentage (BRASIL, 2009).

Mass of 1,000 seeds: it was obtained by weighing eight subsamples of 100 seeds from each replication/treatment. Results were multiplied by 10 and expressed in grams (BRASIL, 2009).

Germination: four subsamples of 50 seeds per replication/treatment were distributed on paper towels ('germitest') moistened with water equivalent to twice the weight of the dry paper. Rolls were made and placed into plastic bags and left for germination at $20^{\circ} \mathrm{C}$. Evaluation of white oat and wheat germination took place 10 and 8 days after sowing, respectively (BRASIL, 2009) and results were expressed as the mean percentage of normal seedlings.

First count of germination: it was performed along with the germination test; the percentages of white oat and wheat normal seedlings were recorded on the fifth and fourth days after sowing, respectively. 
Electrical conductivity: four subsamples of 50 seeds per replication/treatment were weighed and soaked into $200 \mathrm{~mL}$ plastic cups containing $100 \mathrm{~mL}$ of deionized water, for $24 \mathrm{~h}$ at $25^{\circ} \mathrm{C}$ (VIEIRA; KRZYZANOWSKI, 1999); afterwards, the electrical conductivity of the solution was determined through reading in a conductivimeter.

Seedling length: four subsamples of ten seeds per replication/treatment were sown on a line drawn on paper towels ('germitest') moistened with water equivalent to two times the weight of the dry paper. Rolls were made and placed into plastic bags and left for germination in an upright position at $20^{\circ} \mathrm{C}$ for 5 days (NAKAGAWA, 1999). Primary root, shoot and total length of seedlings were measured in $\mathrm{cm}$.

Seedling dry matter: normal seedlings of the seedling length test were placed into paper bags and dried using an oven at $80^{\circ} \mathrm{C}$ for $24 \mathrm{~h}$. Results were obtained dividing each weight by the number of normal seedlings (NAKAGAWA, 1999). Then, the means were obtained for each treatment, in $\mathrm{mg}$.

Data was submitted to variance analysis and means were compared by the Tukey test at a probability level of 5\%, separately for each crop. Person's linear correlation test was performed among Si in plants, tillering and seed quality data.

\section{Results and Discussion}

Leaf application only increased $\mathrm{Si}$ levels in white oat leaves (Table 1), although both crops are classified as Si-accumulative species (MA; MIYAKE; TAKAHASHI, 2001; LIMA FILHO; TSAI, 2007). In Brazil, there have not been yet established ranges for Si deficiency, sufficiency and excess in white oat plants. Nevertheless, both crops showed Si levels above 10.9 and 5.1-16.9 $\mathrm{g} \mathrm{kg}^{-1}$, respectively reported by Korndörfer, Pereira and Nolla. (2004) upon evaluating Si content in plant shoot for white oat and wheat.

Table 1. Silicon ( $\mathrm{Si})$ levels $\left(\mathrm{g} \mathrm{kg}^{-1}\right)$ in plants and tillering of white oat and wheat affected by Si leaf application.

\begin{tabular}{|c|c|c|c|c|c|}
\hline \multirow{2}{*}{ Crop } & \multirow{2}{*}{ Evaluation } & \multirow{2}{*}{$\mathrm{F}_{\text {calc }}$} & \multirow{2}{*}{ C.V. $(\%)$} & \multicolumn{2}{|c|}{ Si application } \\
\hline & & & & With & Without \\
\hline \multirow{3}{*}{ White oat } & $\mathrm{Si}$ & $19.084 * *$ & 7.32 & $13.51 \mathrm{a}^{1}$ & $11.51 \mathrm{~b}$ \\
\hline & Plants $\mathrm{m}^{-2}$ & $0.029 \mathrm{~ns}$ & 15.26 & 336.88 & 332.50 \\
\hline & Panicles $\mathrm{m}^{-2}$ & $6.927 *$ & 15.20 & $501.88 \mathrm{a}$ & $410.63 \mathrm{~b}$ \\
\hline \multirow{3}{*}{ Wheat } & $\mathrm{Si}$ & $0.221 \mathrm{~ns}$ & 13.68 & 15.06 & 14.58 \\
\hline & Plants $\mathrm{m}^{-2}$ & $1.174 \mathrm{~ns}$ & 6.45 & 335.00 & 323.50 \\
\hline & Panicles $\mathrm{m}^{-2}$ & $4.997 *$ & 8.89 & $504.25 \mathrm{a}$ & $456.50 \mathrm{~b}$ \\
\hline
\end{tabular}

${ }^{1}$ Means followed by the same letter in the row do not differ significantly by the Tukey test $(\mathrm{p} \leq 0.05)$.

** and * significant at a probability level of 1 and 5\%, respectively; ns: not significant.

Source: Elaboration of the authors.

Leaf fertilization has been recommended to increase or maintain nutrient concentration in leaves during seed filling period, once Garcia and Hanway (1976) explained that nutrient uptake by root is almost nonexistent in this stage. Nevertheless, this appears to be applied to some specific crops other than wheat.
The number of plants per $\mathrm{m}^{2}$ was similar in both treatments and crops, which was already expected as Si was only sprayed later at tillering, bud differentiation and booting stages (Table 1). Similarly to findings from Ma, Nishimra and Takahashi (1989) in rice, the number of panicles/ spikes per $\mathrm{m}^{2}$ was significantly increased by $\mathrm{Si}$ 
application by $22 \%$ and $10 \%$ in white oat and wheat, respectively, compared to the control, although non significant correlations between $\mathrm{Si}$ content and tillering have been found. According to Figure 1, rainfall was confined until the end of June, followed by a drought period. Afterwards, 104.1 $\mathrm{mm}$ was reported in the beginning of September, in coincidence with different stages of white oat and wheat development, what would explain why tillering of both crops was increased at distinct rates.

According to Table 2, moisture of white oat seeds was not affected by Si fertilization. Marcos Filho (2005) cited the importance of small moisture variations to obtaining consistent results of seed physiological quality.

Table 2. Moisture content and physiological quality of white oat seeds affected by silicon leaf application.

\begin{tabular}{ccccc}
\hline Evaluation & \multirow{2}{*}{$\mathrm{F}_{\text {calc }}$} & C.V. $(\%)$ & \multicolumn{2}{c}{ Si application } \\
\cline { 4 - 5 } & - & - & With & Without \\
\hline Moisture content $(\%)$ & $0.077 \mathrm{~ns}$ & 7.02 & $39.42^{1}$ & 9.21 \\
Mass of 1,000 seeds $(\mathrm{g})$ & $0.761 \mathrm{~ns}$ & 2.97 & $96.00 \mathrm{a}$ & $39.93 \mathrm{a}$ \\
Germination $(\%)$ & $0.761 \mathrm{~ns}$ & 2.97 & $96.00 \mathrm{a}$ & $97.00 \mathrm{a}$ \\
First count $(\%)$ & $0.589 \mathrm{~ns}$ & 9.39 & $69.02 \mathrm{a}$ & $67.79 \mathrm{a}$ \\
Electrical conductivity $\left(\mu \mathrm{S} \mathrm{cm}^{-1} \mathrm{~g}^{-1}\right)$ & $96.759^{* *}$ & 12.44 & $7.23 \mathrm{a}$ & $5.31 \mathrm{~b}$ \\
Primary root length $(\mathrm{cm})$ & $0.953 \mathrm{~ns}$ & 16.25 & $3.33 \mathrm{a}$ & $3.46 \mathrm{a}$ \\
Shoot length $(\mathrm{cm})$ & $39.992^{* *}$ & 11.68 & $10.56 \mathrm{a}$ & $8.77 \mathrm{~b}$ \\
Total seedling length $(\mathrm{cm})$ & $1.534 \mathrm{~ns}$ & 10.87 & $4.87 \mathrm{a}$ & $5.03 \mathrm{a}$ \\
Seedling dry matter $(\mathrm{mg})$ & &
\end{tabular}

${ }^{1}$ Means followed by the same letter in the row do not differ significantly by the Tukey test $(\mathrm{p} \leq 0.05)$.

** significant at a probability level of $1 \%$; ns: not significant.

Source: Elaboration of the authors.

Neither seed mass nor germination varied after Si leaf application. Conversely, Matichenkov et al. (2005) observed increased germination percentage of wheat seeds after Si application, but under saltstress environment. Si influence on seed germination is not only reported in Poaceaes, as observed by $\mathrm{Li}$ and Ma (2002), who cultivated melon under nonstress conditions and found increased activity of protease, lipase and seed vigor. In soybean, Harter and Barros (2011) found positive effects of $\mathrm{Si}$ on soybean germination.

Upon evaluating vigor, Si supply significantly increased root length of white oat seedlings, which also reflected on total length (Table 2); this result is supported by a positive correlation found between Si content is leaves and root and total length $(+0.63$ and +0.55 , respectively). In white oat, higher $\mathrm{Si}$ levels in leaves increased seedling development. Lima Filho and Tsai (2007) did not find any effects of Si supplied at sowing on growth of white oat plants and roots during initial growth stages; however, those same authors observed significant effects in reproductive stages such as reduced size of white oat seeds as Si levels in plants were higher.

Silicon may induce changes in cell wall properties. Some studies about wheat, rice and other Poaceaes show that one of many Si effects on growth is related to increasing size of epidermis cells, especially in basal regions, but not affecting their number. It demonstrates that Si promote one of all three events in cell growth and development, i.e., cell elongation. The other two stages are cell division 
and differentiation (HOSSAIN et al., 2002b). It is already known that $\mathrm{Si}$ decreases cell wall thickness in leaves, by increasing its extensibility and thus general growth (HOSSAIN et al., 2002a); therefore, it is plausible to state that this may also be effective other plant organs. Hattori et al. (2003) studied some changes induced by $\mathrm{Si}$ on mechanical properties in cell walls of sorghum roots and found that this element improved their expansion capacity in apical and subapical regions. Findings from those authors emphasize Si role in root growth, as also observed in this study (Table 2).

Similarly to white oat, moisture content of wheat seeds did not vary after Si application (Table 3), contributing to obtaining consistent results of seed physiological quality (MARCOS FILHO, 2005).

Table 3. Moisture content and physiological quality of wheat seeds affected by silicon leaf application.

\begin{tabular}{ccccc}
\hline Evaluation & \multirow{2}{*}{$\mathrm{F}_{\text {calc }}$} & C.V. $(\%)$ & \multicolumn{2}{c}{ Si application } \\
\cline { 5 - 5 } & - & - & With & Without \\
\hline Moisture content $(\%)$ & $6.076^{*}$ & 8.62 & $36.42^{1}$ & 10.35 \\
Mass of 1,000 seeds $(\mathrm{g})$ & $0.190 \mathrm{~ns}$ & 1.15 & $99.00 \mathrm{a}$ & $35.03 \mathrm{~b}$ \\
Germination $(\%)$ & $0.190 \mathrm{~ns}$ & 1.15 & $99.00 \mathrm{a}$ & $99.00 \mathrm{a}$ \\
First count $(\%)$ & $1.244 \mathrm{~ns}$ & 9.38 & $15.16 \mathrm{a}$ & $14.77 \mathrm{a}$ \\
Electrical conductivity $\left(\mu \mathrm{S} \mathrm{cm}^{-1} \mathrm{~g}^{-1}\right)$ & $1.967 \mathrm{~ns}$ & 7.24 & $8.77 \mathrm{a}$ & $8.55 \mathrm{a}$ \\
Primary root length $(\mathrm{cm})$ & $0.837 \mathrm{~ns}$ & 13.95 & $3.86 \mathrm{a}$ & $3.98 \mathrm{a}$ \\
Shoot length $(\mathrm{cm})$ & $0.149 \mathrm{~ns}$ & 7.81 & $12.63 \mathrm{a}$ & $12.53 \mathrm{a}$ \\
Total seedling length $(\mathrm{cm})$ & $1.007 \mathrm{~ns}$ & 9.30 & $8.55 \mathrm{a}$ & $8.35 \mathrm{a}$ \\
Seedling dry matter $(\mathrm{mg})$ & &
\end{tabular}

${ }^{1}$ Means followed by the same letter in the row do not differ significantly by the Tukey test $(\mathrm{p} \leq 0.05)$.

* significant at a probability level of 5\%; ns: not significant.

Source: Elaboration of the authors.

Mass of wheat seeds was positively influenced by Si leaf application (Table 3) similarly to results of Mauad et al. (2003), in rice. Lima Filho and Tsai (2007) also observed Si benefits in seed mass of white oat and wheat, although benefits were more accentuated in the latter crop. According to Marcos Filho (2005), seed mass varies depending on genotype but it is also influenced by environmental conditions and management practices such as plant nutrition. Those authors cited that seed mass may be related to seed vigor; however, seed germination and vigor were not affected by $\mathrm{Si}$ application, as found for seed mass.

Germination percentage in the first and final count was the same, as all normal seedlings were obtained sooner than the end of the pre-established period for final evaluation (Tables 2 and 3 ).

Although positive effects of Si fertilization on seed quality have been reported by some authors (HARTER; BARROS, 2011; TOLEDO et al., 2011), many benefits in seed germination and vigor are reported as indirect effects of disease suppression (DATNOFF; DEREN; SNYDER, 1997), spikelet fertility (MA; NISHIMRA; TAKAHASHI, 1989) and seed mass (DEREN et al., 1994). Although Lima Filho and Tsai (2007) reported wheat to be more responsive to silicon than white oat, this element seems to be more likely to affect seed quality of this latter crop. 
Whenever plants are cropped under favorable conditions, especially free of diseases, both high quality seeds and yields may be achieved anyway (TOLEDO et al., 2011). Additionally, as Si levels in seeds were higher even with no Si fertilization (Table 1), it was noticed that Si supply was sufficient to producing wheat seeds with high germination and vigor with and without leaf fertilization.

Although plant tillering plays an important role in increasing yield of grasses in general, some studies have shown different quality levels of seeds produced by plants with a variable number of tillers (COIMBRA; NAKAGAWA, 2006). In this study, tillering was not significantly correlated to physiological quality of white oat seeds but was showed negative correlation with shoot length of wheat seedlings $(-0.51 *)$.

\section{Conclusions}

Silicon leaf application increases root and total length of white oat seedlings as an effect of higher $\mathrm{Si}$ level in leaves.

Silicon leaf application increases mass of wheat seeds without affecting germination or vigor.

\section{Acknowledgment}

To "Bioquick Tecnologia" Import and Export of Agricultural Products Ltda. for supplying Silamol ${ }^{\circledR}$ for this research.

\section{References}

BRASIL. Ministério da Agricultura, Pecuária e Abastecimento. Regras para análise de sementes. Brasília: MAPA/ACS, 2009. 399 p.

COIMBRA, R. A.; NAKAGAWA, J. Época de semeadura, produção e qualidade fisiológica de sementes e milheto. Revista Brasileira de Sementes, Londrina, v. 28, n. 2, p. 53-59, 2006.

CONSELHO NACIONAL DE ABASTECIMENTO CONAB. Série histórica. Brasil - por produtos. 2012. Disponível em: <http://www.conab.gov.br/conabweb/
download/safra/BrasilProdutoSerieHist.xls $>$. Acesso em: 3 set. 2012.

COPELAND, L. O.; McDONALD, M. B. Principles of seed science and technology. 4. ed. New York: Chapman and Hall, 2001. 488 p.

DATNOFF, L. E.; DEREN, C. W.; SNYDER, G. H. Silicon fertilization for disease management of rice in Florida. Crop Protection, Oxford, v. 16, n. 6, p. 525-531, 1997.

DEREN, C. W.; DATNOFF, L. E.; SNYDER, G. H.; MARTIN, F. G. Silicon concentration, disease response, and yield components of rice genotypes grown on flooded organic histosols. Crop Science, Madison, v. 34, n. 3, p. 733-737, 1994.

EPSTEIN, E. Silicon. Annual Review of Plant Physiology and Molecular Biology, Palo Alto, v. 50, n. 1, p. 641-664, 1999.

FOOD AND AGRICULTURE ORGANIZATION OF THE UNITED NATIONS - FAO. World soil resources report. Rome: FAO, 2006. (World Reference Base for Soil Resources, 103).

GARCIA, L. R.; HANWAY, J. J. Foliar fertilization of soybeans during the seed-filling period. Agronomy Journal, Madison, v. 4, n. 68, p. 763-769, 1976.

HARTER, F. S.; BARROS, A. C. S. A. Cálcio e silício na produção e qualidade de sementes de soja. Revista Brasileira de Sementes, Londrina, v. 33, n. 1, p. 54-60, 2011.

HATTORI, T.; INANAGA, S.; TANIMOTO, E.; LUX, A.; LUXOVA, M.; SUGIMOTO, Y. Silicon-induced changes in viscoelastic properties of sorghum root cell walls. Plant and Cell Physiology, Oxford, v. 44, n. 7, p. 743-749, 2003.

HOSSAIN, M. T.; KOUICHI, S.; WAKABAYASHI, K.; FUJII, S.; YAMAMOTO, R.; HOSON, T. Silicon stimulates oat leaf growth by modifying cell wall properties. In: SILICON IN AGRICULTURE CONFERENCE, 2., 2002, Tsuruoka. Annals... Tokyo: Japanese Society of Soil Science and Plant Nutrition, 2002a. p. 121-124.

HOSSAIN, M. T.; MORI, R.; SOGA, K.; WAKABAYASHI, K.; KAMISAKA， S.; FUJII, S.; YAMAMOTO, R.; HOSON, T. Growth promotion and an increase in cell wall extensibility by silicon in rice and some other Poaceae seedlings. Journal of Plant Research, Tokyo, v. 115, n. 1, p. 23-27, 2002 b.

KORNDÖRFER, G. H.; LEPSCH, I. Effect of silicon on plant growth and yield. In: DATNOFF, L. E.; KORNDÖRFER, G. H.; SNYDER, G. H. (Ed.). Silicon in agriculture. Amsterdam: Elsevier, 2001. p. 133-147. 
KORNDÖRFER, G. H.; PEREIRA, H. S.; NOLLA, A. Análise de silício: solo, planta e fertilizante. Uberlândia: GPSi/ICIAG/UFU, 2004. 34 p. (Boletim técnico, 2).

KORNDÖRFER, G. H.; SNYDER, G. H.; ULLOA, M.; POWELL, G.; DATNOFF, L. E. Calibration of soil and plant silicon analysis for rice production. Journal of Plant Nutrition, Philadelphia, v. 24, n. 4, p. 1071-1084, 2001.

LEE, K. S.; KAHAN, S. A. B.; RHEE, G. S.; YEON, B. Y.; PARK, J. K. Studies of silica application to nursery beds on rice seedling growth. Research Report of the Rural Development Administration, Plant Environmental, Mycology, Farm Product Utilization of the Korea Republic, Suweon, v. 27, n. 1, p. 23-27, 1985.

LI, Q. F.; MA, C. C. Effect of available silicon in soil on cucumber seed germination and seedling growth metabolism. Acta Horticulturae Sinica, Beijing, v. 29, n. 5, p. 433-437, 2002.

LIMA FILHO, O. F.; TSAI, S. M. Crescimento $e$ produção do trigo e da aveia branca suplementados com silício. Dourados: Embrapa Agropecuária Oeste, 2007. 34 p. (Boletim de Pesquisa e Desenvolvimento, 14).

MA, J. F.; MIYAKE, Y.; TAKAHASHI, E. Silicon as a beneficial element for crop plant. In: DATNOFF, L. E.; KORNDÖRFER, G. H.; SNYDER, G. H. (Ed.). Silicon in Agriculture. Amsterdam: Elsevier, 2001. p. 17-39.

MA, J. F.; NISHIMURA, K.; TAKAHASHI, E. Effect of silicon on the growth of rice plant at different growth stages. Soil Science and Plant Nutrition, Tokyo, v. 35, n. 3, p. 347-356, 1989.

MA, J. F.; YAMAJI, N. Silicon uptake and accumulation in higher plants. Trends in Plant Sciences, Amsterdam, v. 11, n. 8, p. 392-397, 2006.

MALAVOLTA, E.; VITTI, G. C.; OLIVEIRA, S. A. Avaliação do estado nutricional das plantas: princípios e aplicações. 2. ed. Piracicaba: Potafós, 1997. 319 p.

MARCOS FILHO, J. Fisiologia de sementes de plantas cultivadas. Piracicaba: FEALQ, 2005. 495 p.

MARSCHNER, H. Mineral nutrition of higher plants. 2. ed. London: Academic Press, 1995. 889 p.

MATICHENKOV, V. V.; KOSOBRUKHOV, A. A.; SHABNOVA, N. I.; BOCHARNIKOVA, I. A. Plant response to silicon fertilizers under salt stress. Agrokhimiya, Moscow, v. 10, n. 1, p. 59-63, 2005.

MAUAD, M.; CRUSCIOL, C. A. C.; GRASSI FILHO, H.; CORRÊA, J. C. Nitrogen and silicon fertilization of upland rice. Scientia Agricola, Piracicaba, v. 60, n. 4, p. 761-765, 2003.

MELO, S. P.; KORNDÖRFER, G. H.; KORNDÖRFER, C. M.; LANA, R. M. Q.; SANTANA, D. G. Silicon accumulation and water deficit tolerance in brachiaria grass. Scientia Agricola, Piracicaba, v. 60, n. 4, p. 755759, 2003.

MOUSSA, H. R. Influence of exogenous application of silicon on physiological response of salt-stressed maize (Zea mays L.). International Journal of Biology, Toronto, v. 8, n. 2, p. 293-297, 2006.

NAKAGAWA, J. Testes de vigor baseados no desempenho das plântulas. In: KRZYZANOWSKI, F. C.; VIEIRA, R. D.; FRANÇA NETO, J. B. (Ed.). Vigor de sementes: conceitos e testes. Londrina: ABRATES, 1999. cap. 2, p. 2-24.

RAIJ, B. van; ANDRADE, J. C.; CANTARELLA, H.; QUAGGIO, J. A. Análise química para avaliação da fertilidade de solos tropicais. Campinas: Instituto Agronômico, 2001. 284 p.

RAIJ, B. van; CANTARELLA, H.; QUAGGIO, J. A.; FURLANI, A. M. C. Recomendações de adubação e calagem para o Estado de São Paulo. 2. ed. Campinas: IAC, 1996. 285 p. (Boletim técnico, 100).

RODRIGUES, F. A.; MCNALLY, D. J.; DATNOFF, L. E.; JONES, J. B.; LABBE, C.; BENHAMOU, N.; MENEZIES, J. G.; BÉLANGER, R. R. Silicon enhances the accumulation of diterpenoid phytoalexins in rice: a potential mechanism for blast resistance. Phytopathology, St. Paul, v. 94, n. 2, p. 177-183, 2004.

SÁ, M. E. Importância da adubação na qualidade de sementes. In: SÁ, M. E.; BUZETTI, S. (Ed.). Importância da adubação na qualidade dos produtos agrícolas. São Paulo: Ícone, 1994. p. 65-98.

SOUSA, J. V.; RODRIGUES, C. R.; LUZ, J. M. Q.; SOUSA, V. B. F.; CARVALHO, P. C.; RODRIGUES, T. M.; BRITO, C. H. Silicato de potássio via foliar no milho: fotossíntese, crescimento e produtividade. Bioscience Journal, Uberlândia, v. 26, n. 4, p. 502-513, 2010.

TOLEDO, M. Z.; GARCIA, R. A.; MERLIN, A.; FERNANDES, D. M. Seed germination and seedling development of white oat affected by silicon and phosphorus fertilization. Scientia Agricola, Piracicaba, v. 68, n. 1, p. 18-23, 2011.

TUNA, A. L.; KAYA, C.; HIGGS, D.; MURILLOAMADOR, B.; AYDEMIR, S.; GIRGIN, A. R. Silicon improves salinity tolerance in wheat plants. Environmental and Experimental Botany, Amsterdam, v. 62, n. 1, p. 10-16, 2008.

VIEIRA, R. D.; KRZYZANOWSKI, F. C. Teste de condutividade elétrica. In: KRZYZANOWSKI, F. C.; VIEIRA, R. D.; FRANÇA NETO, J. B. (Ed.). Vigor de sementes: conceitos e testes. Londrina: ABRATES, 1999. p. 1-26. 
